\title{
都市の上空を流れる風 \\ Wind and Turbulence in Urban Boundary Layers
}

\author{
神田学*1 稲垣厚至*2 瀧本浩史 ${ }^{* 3}$ \\ Manabu KANDA, Atsushi INAGAKI, Hiroshi TAKIMOTO
}

1.はじめに 〜本論の構成と対象とする都市〜

本論では, 都市の上空を流れる風について，ここ数年 以内に得られた研究成果を中心に紹介寸る。限られた紙 面上, 都市気象全般に関わるレヴィユーについては他に 譲ることとし 1, 2), 3) 4), 5), まず, 研究推進の駆動力となっ ている 3 つの技術的側面を指摘した後, 風工学において 留意すべきと考えられる都市の風に関する学問体系上の 重要な知見について, 章毎に整理し, 述べていくことに する。

\section{1 対象とする都市}

都市の幾何形状や土地利用はあまりにも多様であるた め, 本論で取り扱う都市の範疇を明確にしておく必要が ある。それには，水平方向に平均化することによって極 端に単純化した都市大気境界層の鉛直構造の概念図が役 立つであろう（図 1）。極端な高層建物のない都市領域の 大気境界層（図 1(a)）は，大規模な熱的乱流渦が卓越す る混合層（上部）と，建物群によるシアーなど機械的乱 流渦が支配的となる接地境界層（下部）の 2 層構造とな る。2つの層は, 渦スケールが異なるため, 異なる物理 相似則・スケーリングが適用される。本論で扱うのは,
接地境界層（接地層）である。接地境界層は，さらに， (1)地面から最大建物高さまでのキャノピー層（下部）= いわゆる街区内の流れ，(2)Monin-Obukhov 相似則 （MOST）が成立する慣性底層（上部）=中立時はいわ ゆる対数則の流れ，(3)両者の遷移層としての粗度底層 (中 部）に分類される。このような分類になじむ都市は，以 下の章で述べる風・乱流の普遍的特性が基本的に成立す る。一方, 東京スカイツリーのように建物が混合層に突 き出してしまうほどの都市（図 1(c)）には適用できず, 個別に風速場を解析する必要がある。接地層の高さは, 大気境界層の $10 \%$ 程度なので, $1 \mathrm{~km}$ の大気境界層で $100 \mathrm{~m}$ 程度となる。一方, 慣性底層は最大建物高さの 2 〜3 倍程度なので, 慣性底層が接地境界層内（100m）に 収まるためには，建物高さ $20 \sim 30 \mathrm{~m}$ が目安となる。

\section{2 技術的側面一鍵となる技術的進展}

（1）CFD の都市境界層への応用

大規模並列計算機など計算機資源の向上により, LES などによって個々の建物を解像しつつ, 都市街区の風・ 乱流構造を解析することが可能となってきた。

（2）PIV など先端実験技術の都市境界層への応用

*1 東京工業大学 国際開発工学専攻 教授

Professor, Department of International Development Engineering, Tokyo Institute of Technology

$* 2$ 東京工業大学 国際開発工学専攻 助教

Assistant Professor, Department of International Development Engineering, Tokyo Institute of Technology * 3 電力中央研究所 研究員

Researcher, Central Research Institute of Electric Power Industry 
PIV 技術を室内や室外の都市スケールモデルに適用す ることによって, LES との照合だけでなく，大気污染物 質の間欠的拡散との関連性も議論されつつある。

（3）現地観測データのコンパイル・総合的理解

2000 年以降, 世界中のタワー観測データから得られた 都市境界層の風・乱流構造に関する分析が進み, $\mathrm{CFD,}$ 実験と合わせて，その総合的理解が進んだ。

\section{3 学問体系上の知見}

（1）実験室のデータを現実大気に適用する場合，スケ 一ル相似則の補正が必要である。

（2）慣性底層の乱流組織構造は，地表面幾何によらず 普遍的である。

（3）慣性底層の乱流組織構造は, 街区の風や拡散と強 くカップリングしている。

以下の章で，上記それぞれについて説明する。繰り返 すが，図 1(c)のような極端な高層建築を含む都市の風・ 乱流場の一般化は難しく, 現在のところ個別に分析して いくしかない。そのような場合でも，層分類が成り立つ 都市の風・乱流の知見をべースに，それがどのように変 更されるかという切り口で考えていくことは可能である う。

(a)

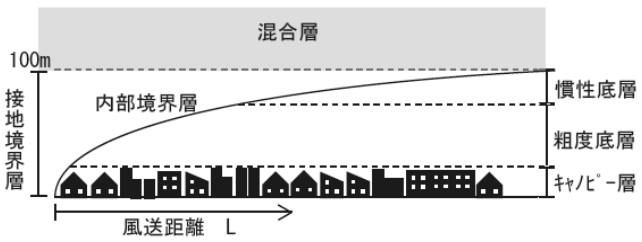

(b)

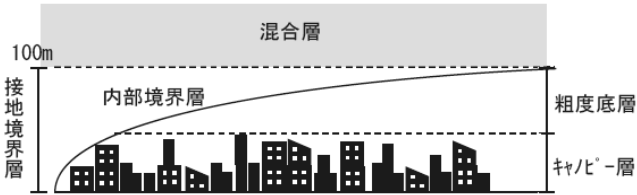

(c)

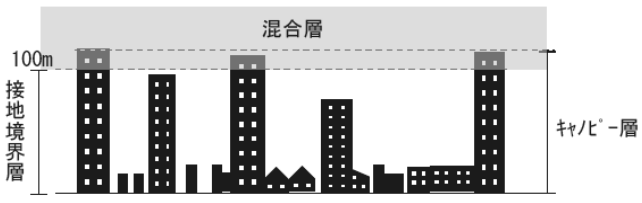

図 1 内部境界層の空間的発達の概念図 (a) 低・中層建 築 (建物高さ $<30 \mathrm{~m})(\mathrm{b})$ 中・高層建築 $(=30 \sim 100 \mathrm{~m})$, (c) 超高層建築 $(>100 \mathrm{~m})$

接地境界層の高度は大気境界層の $10 \%$ 程度で $100 \mathrm{~m}$ は目 安。慣性底層が存在するには, 建物高さが, 接地境界層 の $1 / 2 \sim 1 / 3$ 以下であり, かつ, 風上方向に建物高さの 20
〜30倍の広がりをもつ街でなければならない。

2. 実験室データを現実大気に適用する場合スケール相 似則の補正が必要である

\section{1 現地・実験・計算の相互比較}

Monin-Obukhov 相似則（以下 MOST）によれば，慣 性底層の各種乱流量を適切に接地境界層の代表物理量で スケーリングすれば，地表面粗度によらない普遍的な值 になるはずである。図 2 は, 摩擦速度で無次元化された 風速 3 成分の乱流分散量の鉛直分布を示している 6 。 界中の現地タワーデータ範囲 (ハッチング), 縮尺 $1 / 5$ の 屋外模型実験 (COSMO) データ, 風洞実験データ, LES データを, 統合している。無次元高さ（縦軸）は，地表 面高さからゼ口面変位を引いた実質的な高度を, 流体力 学的粗度で除している。3成分とも, とりわけ水平風速 成分は，普遍量とはならず，データにより大きな差異が みられる。この差異は, 上部の混合層に存在する大規模 な熱対流による渦の影響であることがわかっている（後 述する図 4 の混合層の大きな渦を参照)。現実都市は, 上 部に混合層があり，その大規模渦の乱れの影響を受ける ので, 無次元分散量は, 混合層のような大規模渦の影響 を受けない実験データよりも大きくなる。屋外実験であ る COSMO も, 混合層の影響を大きく受ける。しかし, 混合層の渦は接地境界層の渦よりはるかに大きいので, 物理的なフィルターによって合理的かつ容易に除去する ことが可能である。そのようなフィルターによるノイズ 除去により実験データ（普遍量）と一致する。立方体建 物の配列を解像した大気混合層の LES でも混合層の影 響で普遍量に一致しないが, COSMO と同様の物理フィ ルターを施すと，混合層の影響が消えて，実験データの 普遍量に一致する。つまり, 現地・実験・計算間の無次 元分散量の互換性を担保するには, 混合層の渦の影響を 物理的に考慮しなければならない。非常に幸いなことに, 混合層の渦の影響は, 慣性底層におけるフラックスなど の物質輸送に関わる相似側には影響を及ぼさない。

2. 2 混合層の高さと流体力学的粗度の比によって, 無次元分散量は補正できる

無次元分散の普遍量からのずれは, 混合層の大規模渦 の影響によるため, 混合層と接地層の長さスケールの比, 具体的には, 混合層高さと地表面粗度の比, によって良 好に説明できる7) (図 3)。実在の都市では, 現業の気象 予報やリモートセンサによって, 混合層高度の情報は比 較的容易に入手できるので，室内実験などで対象とする 街区の地表面粗度がわかれば, 図 3 を基に無次元分散量 を補正して，現地に適用できる。 


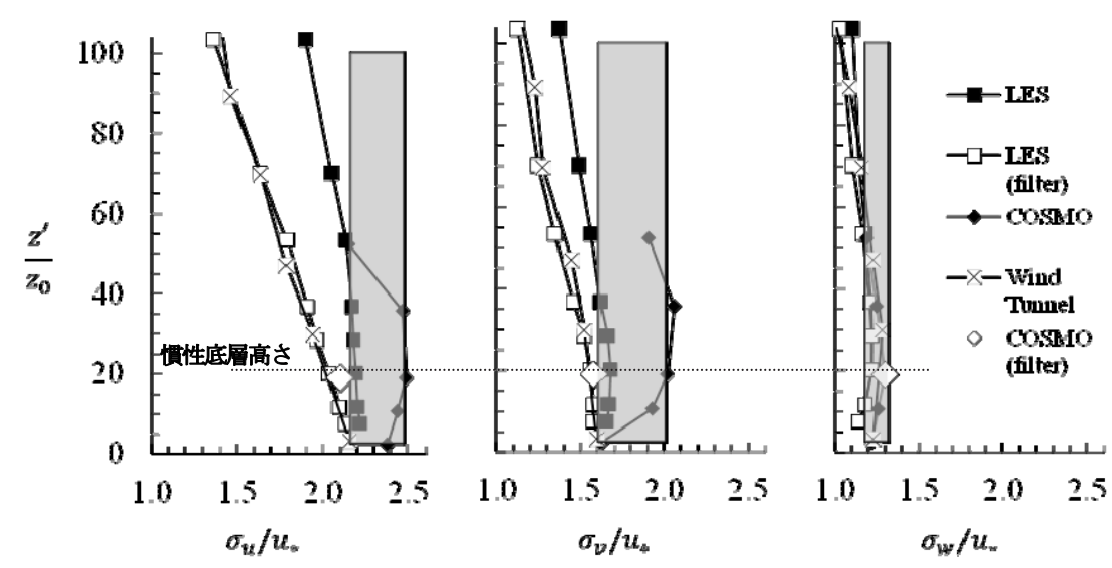

図 2 摩擦速度 $u_{*}$ で無次元化された風速 3 成分の乱流分散量 $\left(\sigma_{u}, \sigma_{v}, \sigma_{w}\right)$ の鉛直分布 $\left.{ }^{6}\right)$ 世界中の現地タワーデータ 範囲 (ハッチング), 縮尺 $1 / 5$ の屋外模型実験 (COSMO) データ，風洞実験データ，LES データ

無次元高さ (縦軸) は, 地表面高さ $z$ からゼロ面変位 $d$ を引いた実質的な高度 $z^{\prime}(=z-d)$ を, 流体力学的粗度 $z_{0}$ で除 している。フィルターにより混合層の影響を取り除くと風洞実験結果にすべて一致する。

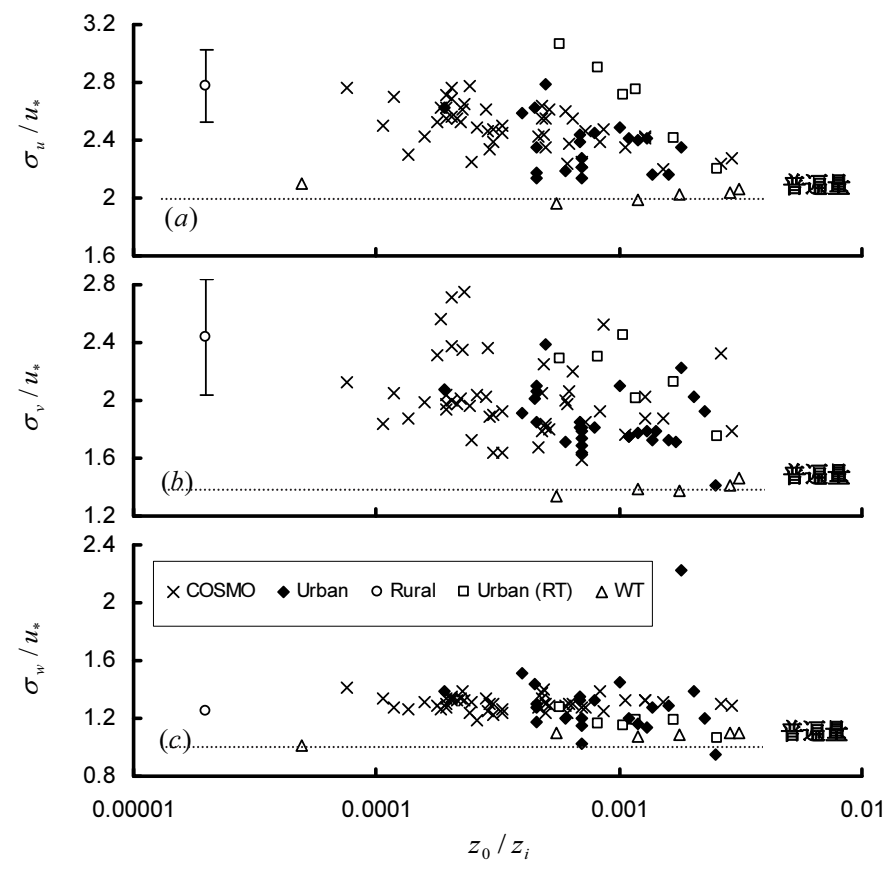

図 3 摩擦速度 $u_{*}$ で無次元化された風速 3 成分の乱流分散量 $\left(\sigma_{u}, \sigma_{v}, \sigma_{w}\right)$ (縦軸) に対する混合層高さ $\left(z_{i}\right)$ に対す る地表面の流体力学的粗度 $\left(z_{0}\right)$ の比 (横軸) との関係 7)

現地観測（Urban およびRural）・COSMO（フィルターによる混合層影響の除去はなし）・風洞実験(WT)。混合層影 響がない場合， 3 成分の無次元分散量は，慣性底層内で，それぞれ，およそ2.0, 1.3, 1.0 前後の值（普遍量）に近づく。 
3. 慣性底層における乱流組織構造は, 地表面幾何に よらず普遍的である

3. 1 混合層の組織構造と接地境界層の組織構造

図 4 は, 混合層と接地境界層の乱流組織構造の違い を概念化したものである。混合層の渦は, 熱的乱流が 支配的であり, より大規模な渦となる。通常, 一般風 (あるいはシアー) の強さによって, 静穏時には, 亀 の甲羅のような対流パターンが，シアーが強い場合に は, 日本海の筋状雲に見られるようなロール対流とな ることが知られている。後者は, 筋状になることから, 以下に述べる慣性底層中の代表的乱流構造である低速 ストリークと混同されることが多い。どちらもシアー が関与している点では同じであるが，その成因と起源 や渦スケールが大きく異なることから, 区別して議論 すべきであろう。以下は，概念図の下部（接地境界層） に芋虫のように描かれた乱流組織構造（ストリーク） の普遍性に関する話である。

\section{Conceptual model}

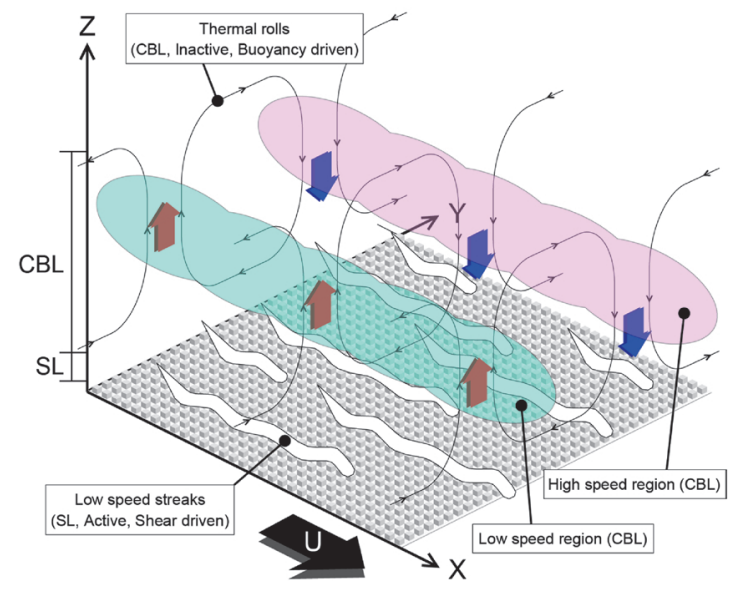

図 4 混合層 $(\mathrm{CBL})$ と接地層(SL)における乱流組織構造 の概念図

混合層では熱駆動の大規模渦が支配的であり，接地層 の無次元風速変動には影響を及ぼすが，接地層のフラ ックスには影響しない (inactive)。

\section{2 慣性底層の乱流組織構造の普遍性}

PIVによる風洞実験, LES による数值実験によって, 様々な建物形状に対する解析が蓄積されてくることに より, 慣性底層の乱流組織構造がかなり普遍的である ことがわかってきた。もちろん, 運動量輸送や地表面
摩擦そのものの值は，同じ風速条件下でも地表面性状 によって大きく異なるので，適切なスケーリングによ って正規化を行う必要がある。瀧本による風洞実験結 果を紹介しよう 8)。4種類の異なる地表面形状の粗度 配列（うち 1 つは平板）の上空に発達する乱流組織構 造をPIV 法で捉えて比較した (図 5)。図6 は, それぞ れの地表面条件に対する異なる高度の水平断面での乱 流組織構造を表している。グレースケールは, 摩擦速 度で無次元化した水平風速の変動成分（平均風速を差 し引いている）であり, 黒い部分は速度変動がマイナ ス，つまり平均風速よりも低速部である。無次元高さ

（ ）は, 風洞床面からの実質高さを境界層高度で除 したものである。いわゆる主流方向に長細い低速ス卜 リークがどの地表面形状上空にも現れている。低速ス トリークは曲がりくねって捉えにくいので，2 点相関 係数の分布を図化すると定量的に比較できるようにな り, ストリークに対応する横長の乱流構造が浮かび上 がってくる (図 7)。2 点相関係数にあるしきい值を設 けて, 乱流構造の主流方向スケール $(\mathrm{Lx})$ と横断方向 スケール $(\mathrm{Ly})$ の比（=アスペクト比）をとってみよ う。これを風速のシアー(縦軸) と関連付けてプロッ トすると, 慣性底層内の風速シアーに依存する形で, 乱流構造のアスペクト比が一定値（=普遍量）となる ことがわかる（図 8)。

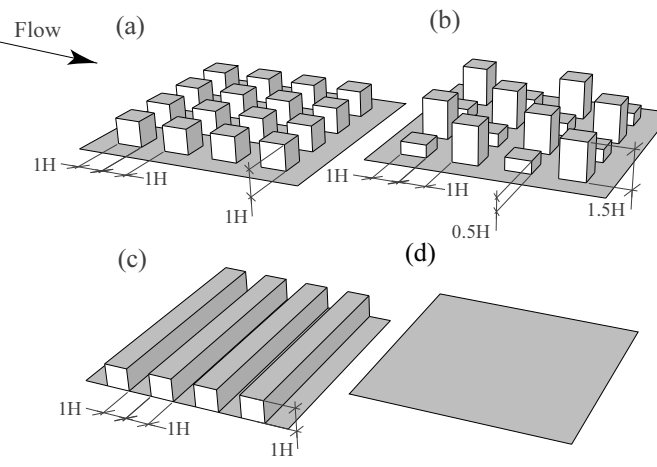

図 5 風洞実験に使用された 4 タイプの地表面性状 (a) $\mathrm{SQ}$ (立方体の正方配列), (b) HV（高さの異なる直方 体の交互配列），(c) 2D（2 次元粗度）,(d) FL（平板） 
(a)

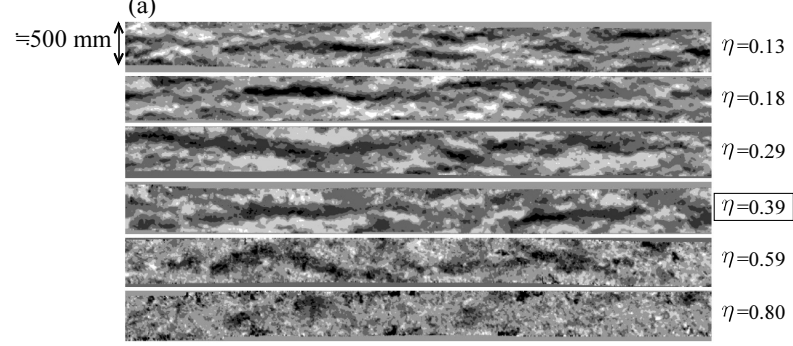

(b)

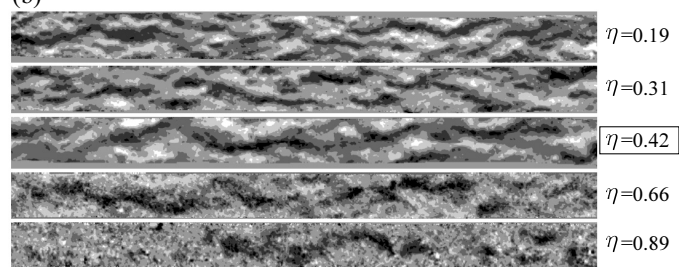

(c)

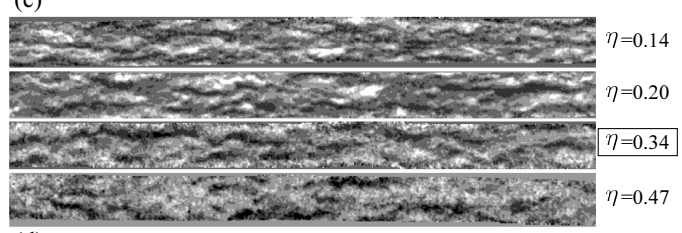

(d)
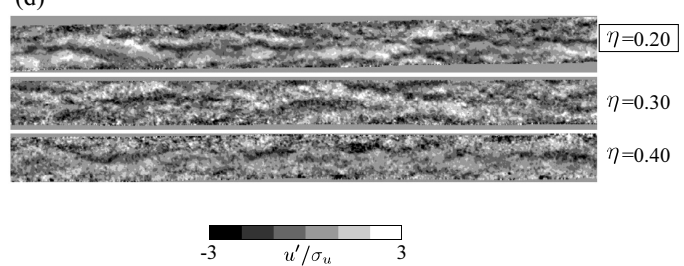

図6 摩擦速度で無次元化した風速変動(平均風速を差し引いている)の瞬間的な水平断面図 横軸が風洞の主流方向, 縦軸がスパン方向。上から, (a) SQ, (b) HV, (c) 2D, (d) FL

無次元高さ $(\eta)$ は, 風洞床面からの実質高さを境界層高度 $(\sigma)$ で除したものである。とりわけ慣性底層内の高度で は（それぞれ $\eta=0.39,0.42,0.34,0.20$ で枠囲い），お互いに似たようなストリーク構造の存在が確認できる。

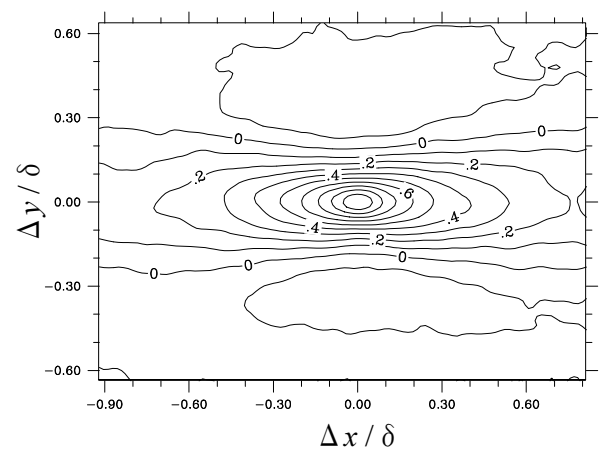

図 7 主流風速変動の 2 点相関係数の水平断面図の例 これにより, 乱流組織構造の幾何学的大きさを表現す る尺度とする。

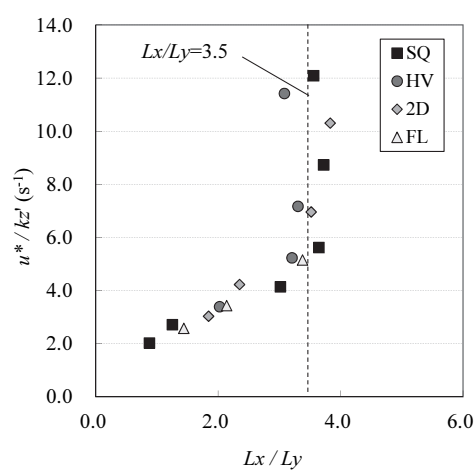

図 82 点相関係数の分布図から得られた乱流組織構 造のアスペクト比（横軸は, 主流方向長さ/横断方向 長さ)。縦軸は，風速の鉛直シアー。地表面によらず， 慣性底層で，アスペクト比 3.5 程度で一定となる。 
4. 慣性底層の乱流組織構造は, 街区の風や拡散と強 くカップリングしている

4. 1 キャノピー層から慣性底層へのフラッシング キャノピー層の流れに目を向けてみよう。単純な正 方配列の立方体群のキャノピー内では，平均流はよく 知られた循環渦となるが, 実際の乱流場は, きわめて 非定常性が強い. Takimoto8)によれば，瞬間的な流れ 場は 5 つに分類されるが, 図 9 には代表的な 3 つを示 した (循環渦, 複数渦, フラッシング)。この中で特筆 すべきは，フラッシングである。あるキャノピー空間
の全体にわたって大規模な上昇流モードとなっている。 フラッシングでは，キャノピー上端部で，通常の 4 倍 程度の運動量フラックスを持っており, 街区内からの 物質輸送に大きな影響を及ぼす。このフラッシングは, 上空に存在する大規模な乱流の低速構造と密接に関係 して, 局所的に乱れの強い境界層の前縁部よりも，十 分に発達し, 大きな乱流構造が存在する境界層の下で, より頻繁に観測される 9)。これらのフラッシングは, COSMO でも観測されている。
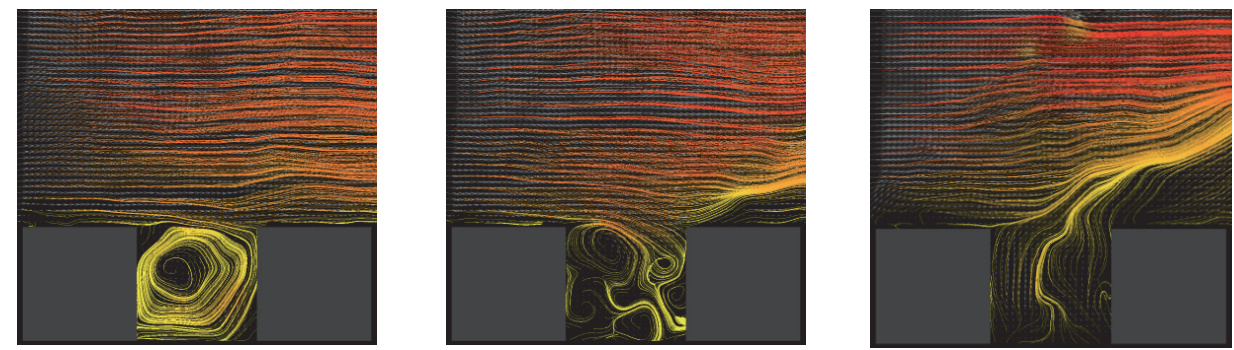

図 9 立方体粗度群のキャノピー層内における瞬間的な流れパターンの分類（風洞実験結果） 左から, 循環渦, 複数渦, フラッシングの 3 パターンを示した。この他に, 後方流れ, 発散流れの 2 つを加えて 5 パタ ーンがある 8)。特に，フラッシングは，街区内の污染物質の換気に重要な役割を果たしている。

4. 2 慣性底層の乱流組織構造と 2 次元街区の污染 物質拡散のカップリング

図 10 は, Michioka et al. 10)による 2 次元建物配列を 対象とした風洞実験を模した LES の結果である。図中
央のキャニオン床部からは污染物質と見なしたトレー サー (カラーマップ) が放出されているが, 注目す心゙ き点は，上空の慣性底層における低速ストリーク（図 中グレーハッチング）に対応して，キャニオン内のト レーサーが上空に巻き上げられている点である。

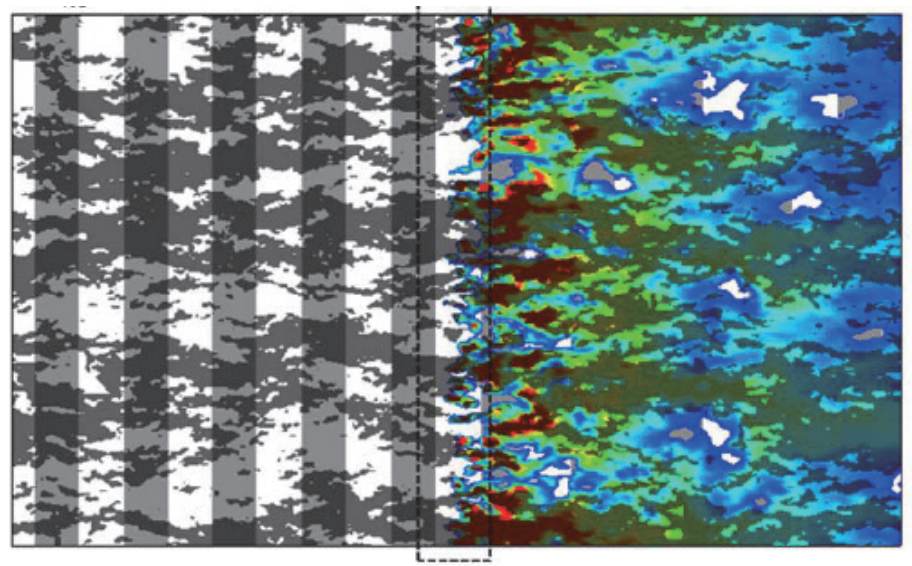

図 10 LES による 2 次元粗度配列上空における低速ストリーク (図中の濃いグレ一領域) とトレーサーの無次元濃度 10）(カラーコンター)。流れは左から右。規則的な白黒の縦縞は 2 次元粗度配列で白い部分には粗度がなく，床が見え ている。図中央の点線部床面からトレーサーが放出され，低速ストリークに対応するかのように巻き上げられている。 
4. 3 慣性底層の乱流組織構造と 3 次元街区内の風 のカップリング

図 11 は, Inagaki et al.11による 3 次元正方配列の立 方群を対象とした大気境界層を模した LES の結果で ある。図左上(a)だけが建物の 2 倍の高さの慣性底層に おける主流風速変動（平均風速を差し引いている）の 瞬間的な水平断面図を示し, 青色が低速ストリークで ある。(b)(c)(d)(e)は。いずれも街区内の建物高さの 0.125 倍つまり床にかなり近い高さにおける, u, v, w, T の変動量の水平断面図である。街区内の風・乱流が上
空のストリーク構造と強く相関していることがわかる だろう。例えば，(c)の横断風速変動成分 $\mathrm{v}$ は，上空の 低速ストリーク (ハッチング) にあたかも吸い寄せら れるかのように床面で筋状に収束している。これに対 応して, 床面近傍の温度(e)も低速ストリーク部に沿う ように水平収束によって高温化している。床による拘 束条件により，上昇流成分(d)の対応はあまり明確でな いように見えるが， 4.1 で述べたフラッシング現象も， この低速ストリークに沿いに集中している。

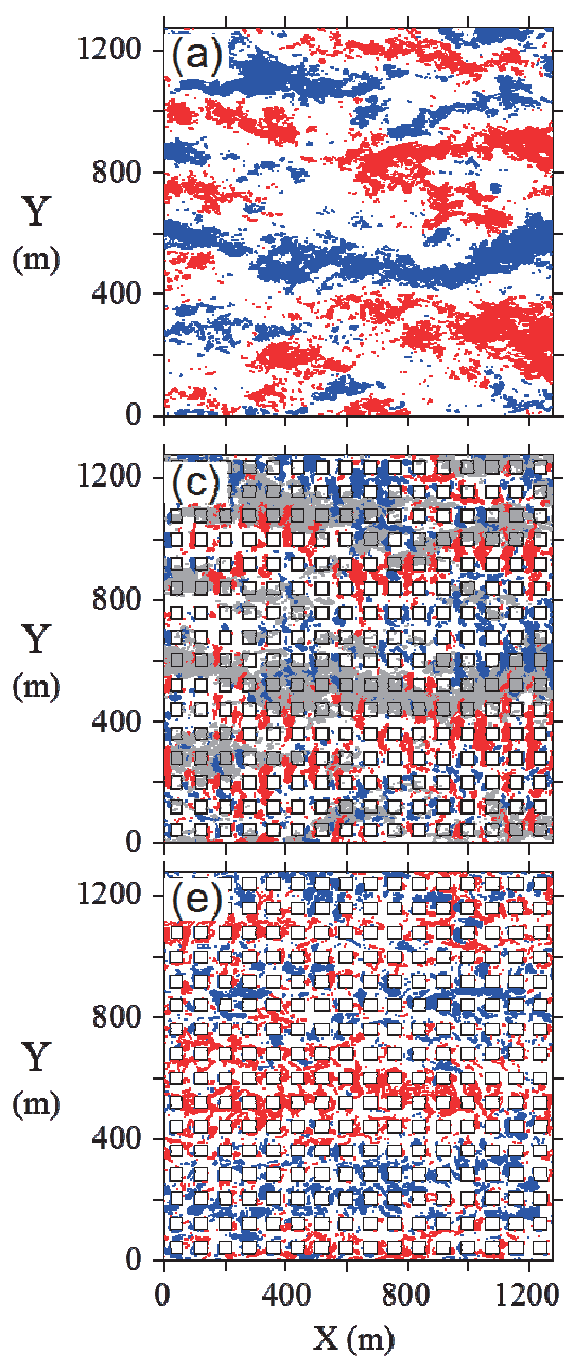

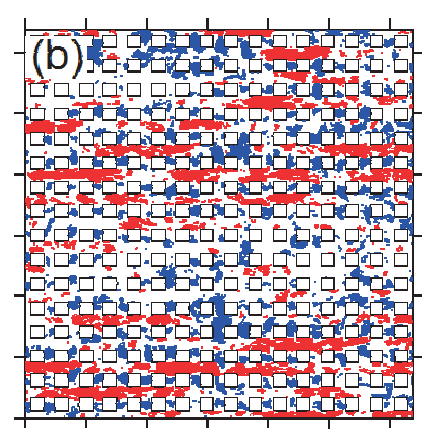

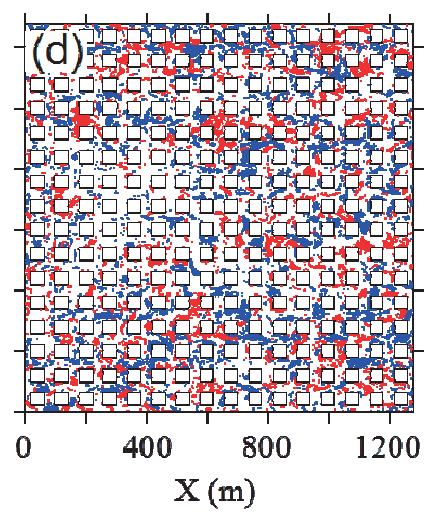

Non-dimensional $u^{\prime}, v^{\prime}, w^{\prime}, T^{\prime}$

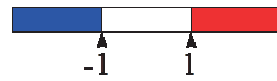

\section{Non-dimensional $\mathrm{u}^{\prime}$ at $2 \mathrm{H}$}

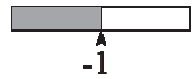

図 113 次元正方配列の立方群を対象とした大気境界層を模した LES の結果 ${ }^{11)}$

(a)建物上空 2 倍の高さの慣性底層における主流風速変動の瞬間的な水平断面図を示し，青色が低速ストリークである。 (b)(c)(d)(e)は, 街区内の建物高さの 0.125 倍つまり床にかなり近い高さにおける, u, v, w, T の変動量の水平断面図。(c) の図中のハッチングは，(a)の慣性底層内の低速ストリークを表している。 


\section{5. おわりに}

東京・名古屋の実在の 3 次元建物データベースを基 にして, 120 以上の街区にLES を適用するプロジェク 卜を実施しているが，驚いたことに，かなりの高層建 築を含む街区でも, $1 \mathrm{~km}$ 四方程度の水平断面平均場を 対象とすれば, 従来の MOST や流体力学的粗度のアプ ローチが概ね適用できることがわかってきている 12)。 都市だからと言って, 風・乱流構造の一般的抽象は困 難であるとか，従来のアプローチは全く適用できない といった考えは極端かつ危険であり，まずは，ほとん どの都市領域にあてはまるような普遍的特徵を踏まえ たうえで，それをべースに，それが適用できない特殊 な都市幾何構造における風・乱流を別途考えていくの が良いのではないだろうか。

\section{謝辞}

本研究は, 文部科学省の委託事業「気候変動適応研 究推進プログラム」, 日本学術振興会科学研究費補助金 基盤研究 B（課題番号: 21360233）及び若手研究（B)

(課題番号:23760454 及び 21760382), 特別研究員奨 励費（課題番号：09J09416）による支援を受けた。こ こに謝意を表します。

\section{参考文献}

1) Kanda, M., "Progress in the scale modeling of urban climate", Theoretical and Applied Climatology, Vol.84, pp. 23-34, (2006).

2) Kanda, M., "Progress in urban meteorology: A review", Journal of the Meteorological Society of Japan, Vo.185, pp, 363-383, (2007).

3) 神田 学, 稲垣 厚至, 「都市境界層における乱流相 似則と組織構造」, 日本流体力学会機関紙 ながれ, Vol.26, pp. 361-368, (2007).

4) 神田 学, 稲垣 厚至, 「屋外都市スケールモデル実 験 COSMO のねらいと成果」, 日本風工学会誌, Vol.33, No. 4, (2008).

5) 神田 学 編, 気象研究ノート「都市の気象と気候」, 日本気象学会, pp224, (2012).

6) Castillo, M. C., Inagaki, A., and Kanda, M., "The effects of inner and outer layer turbulence of a convective boundary layer in the near-neutral inertial sublayer over an urban like surface", Boundary-Layer Meteorology, Vol. 140, No.3, pp. 453-469, (2011).
7) Inagaki, A. and Kanda, M., "Turbulent flow similarity over an array of cubes in near-neutrally stratified atmospheric flow", Journal of Fluid Mechanics, Vol. 615, pp, 101-120, (2008).

8) Takimoto, H., "Coherent Flow Structures within and above Simplified Building Arrays", Doctor thesis, Tokyo Institute of Technology, (2012).

9) Takimoto, H., Sato, A., Barlow, J. F., Moriwaki, R., Inagaki, A., Onomura, S. and Kanda, M., "Particle Image Velocimetry Measurements of Turbulent Flow Within Outdoor and Indoor Urban Scale Models and Flushing Motions in Urban Canopy Layers", Boundary-Layer Meteorology, Vol. 140, No. 2, pp. 295-314, (2011).

10) Michioka, T., Sato, A., Takimoto, H. and Kanda, M., "Large-Eddy Simulation for the Mechanism of Pollutant Removal from a Two-Dimensional Street Canyon", Boundary-Layer Meteorology, Vol. 138, No. 2, pp. 195-213, (2011).

11) Inagaki, A., Castillo, M. C., Yamashita, Y., Kanda, M. and Takimoto, H., "Large eddy simulation study of coherent flow structures within a cubical canopy", Boundary-Layer Meteorology, Vol. 142, pp, 207-222, (2012).

12）宮本 崇史, 稲垣 厚至, 神田 学, 「3 次元建物 GIS を用いた LES による東京街区の流体力学的パラメ タリゼーション」, 水工学論文集, Vol. 56, pp. 1801-1807, (2012). 